\title{
Perubahan Kompensasi Berdasarkan Peraturan Menteri Kesehatan Nomor 28 Tahun 2014 pada Pegawai Puskesmas Kota Cimahi
}

\author{
Sekky Intania ${ }^{1}$, Nanan Sekarwana ${ }^{2}$, Guswan Wiwaha ${ }^{3}$ \\ ${ }^{1}$ Dinas Kesehatan Kota Cimahi \\ ${ }_{2}^{2}$ Departemen Ilmu Kesehatan Anak, Fakultas Kedokteran Universitas Padjadjaran/ \\ Rumah Sakit Umum Pusat Dr. Hasan Sadikin, Bandung \\ ${ }^{3}$ Departemen Ilmu Kesehatan Masyarakat, Fakultas Kedokteran Universitas Padjadjaran
}

\begin{abstract}
Abstrak
Perubahan kompensasi pelayanan kesehatan Puskesmas berdasarkan Permenkes 28/2014 menimbulkan persepsi negatif berupa ketidakpuasan kerja di kalangan pegawai. Dugaan ketidakpuasan kerja ditunjukkan dengan adanya turnover kepala puskesmas sebanyak 38,46\% di Kota Cimahi pada tahun 2014-2015. Penelitian dilakukan untuk menganalisis perbedaan kompensasi finansial sebelum dan sesudah penerapan Permenkes 28/2014 pada Pegawai Puskesmas di Kota Cimahi. Pada penelitian ini digunakan metode observasional dengan rancangan cross sectional. Telah dipilih 150 pegawai sebagai sampel secara stratified random sampling. Data kompensasi finansial sebelum dan sesudah penerapan Permenkes 28/2014 merupakan data sekunder dari Dinas Kesehatan. Kedua data dianalisis dengan uji komparatif rata-rata dua sampel berkorelasi Wilcoxon. Penelitian ini dilaksanakan pada bulan Agustus - November 2016 diseluruh puskesmas di Kota Cimahi. Hasil penelitian menunjukkan terdapat perbedaan yang siginfikan antara kompensasi finansial sebelum dan sesudah penerapan Permenkes 28/2014 pada Pegawai Puskemas. Adanya variabel daerah pada Peraturan Menteri Kesehatan Nomor 28 Tahun 2014 dinilai baik.
\end{abstract}

Kata Kunci : Permenkes 28/2014, Perubahan kompensasi, Puskesmas

\section{Compensation Changes Based on Health Minister Decree Number 28 of 2014 at Public Health Center Workers in Cimahi}

\begin{abstract}
Changes of Public Health Center services' compensation based on Health Minister Decree Number 28/2014 revealed negative perception in the form of job dissatisfaction among employees. Alleged job dissatisfaction indicated by the turnover of public health centers' heads as much as 38.46\% in Cimahi in 2014-2015. The study was conducted to analyze the differences in financial compensation before and after the implementation of Health Minister Decree Number 28/2014 to the Employees of Public Health Center in Cimahi. Observational method was applied for this study with cross sectional design. Up to 150 employees have been chosen as sample by stratified random sampling. Financial compensation data before and after the implementation of Health Minister Decree Number 28/2014 is secondary data from the Health Office. Data were analyzed with Wilcoxon Match Pairs Test. This research was conducted in August - November 2016 at all health centers in Cimahi City. The result of the study showed the existence of significant difference among financial compensation before and after the implementation of Health Minister Decree Number 28/2014 to the Public Health Centers' employees. The presence of regional varible in the Health Minister Decree, public health care.
\end{abstract}

Keyword : Compensation changes, Health Minister Decree, public health centre.

Korespondensi:

Sekky Intania, drg

Dinas Kesehatan Kota Cimahi

Komplek Perkantoran Pemkot Cimahi, Gedung C Lt. 3, Jl. Raden Demang Hardjakusumah, Kota Cimahi.

Mobile : 081809878844

Email : sekky.intania@yahoo.co.id 


\section{Pendahuluan}

Sistem pembiayaan JKN dikelola oleh Badan Penyelenggara Jaminan Sosial (BPJS). Dalam pengelolaannya ditemukan permasalahan pada pengaturan jasa pelayanan bagi tenaga kesehatan di Puskesmas. Pemerintah telah menetapkan Permenkes No 19 Tahun 2014 tentang Penggunaan Dana Kapitasi JKN untuk Jasa Pelayanan Kesehatan dan Dukungan Biaya Operasional pada FKTP milik Pemerintah. Salah satu acuan yang digunakan dalam pengaturan jasa pelayanan kesehatan ini melalui penilaian ketenagaan. Diketahui terdapat kesenjangan nilai yang dipandang terlalu lebar antara tenaga medis diberi nilai 150 dengan tenaga kesehatan setara D4/S1 diberi nilai 60. Pemerintah telah berupaya menyelesaikan masalah kesenjangan nilai dengan mengeluarkan Permenkes No 28 Tahun 2014 tentang Pedoman Pelaksanaan Program JKN. Dalam Permenkes ini ditambahkan variabel daerah, namun upaya Pemerintah ini belum dapat meminimalisasi persepsi pegawai terhadap kesenjangan nilai tersebut. Adanya kesenjangan nilai berimbas pada kurang proporsionalnya jasa pelayanan yang diterima oleh pegawai puskesmas. ${ }^{1-2}$ Kompensasi merupakan hal yang penting bagi pegawai maupun organisasi, baik bersifat finansial maupun non finansial. ${ }^{3}$ Jasa pelayanan JKN yang diperoleh pegawai puskesmas merupakan salah satu bentuk kompensasi finansial. ${ }^{4}$ Kompensasi merupakan pendapatan, jaminan bagi kelangsungan hidup pegawai serta mencerminkan ukuran nilai karya baik terhadap pegawai itu sendiri, keluarga maupun masyarakat. ${ }^{4}$ Salah satu tujuan pemberian kompensasi adalah terciptanya kepuasan kerja pegawai, pegawai bekerja keras memenuhi kebutuhannya dan mencapai tujuan organisasinya. ${ }^{5}$

Kota Cimahi hingga saat ini memiliki 13 Puskesmas yang tersebar di 3 kecamatan dan 14 kelurahan, masing-masing dipimpin oleh seorang kepala puskesmas. Berdasarkan data kepegawaian Dinas Kesehatan Kota Cimahi, diketahui sejak diberlakukannya program JKN, mulai 1 Januari 2014 sampai pertengahan tahun 2015, telah terjadi turnover kepala puskesmas sekitar 38,46\%. Tingginya turnover pegawai dapat menjadi salah satu indikasi rendahnya kepuasan kerja pegawai di tempat tersebut. ${ }^{5}$

Dengan demikian perlu dilakukan penelitian untuk mendapatkan informasi apakah terdapat perbedaan kompensasi finansial sebelum dan sesudah penerapan Permenkes 28/2014, karena bermanfaat sebagai bahan evaluasi terhadap Permenkes 28/2014 dalam hal pembagian jasa bagi pegawai puskesmas.

\section{Metode}

Penelitian ini menggunakan metode observasional dengan rancangan cross sectional. Dipilih sampel sebanyak 150 pegawai berdasarkan Rasch Model menurut Linacre dengan tingkat ketelitian pengukuran $\pm 0,5$ logit dan tingkat kepercayaan 99\%. ${ }^{6}$ Sampel diambil dengan teknik stratified propotionate random sampling memenuhi kriteria inklusi yaitu pegawai puskesmas baik berstatus PNS maupun Non PNS dengan masa kerja minimal 3 tahun dan kriteria ekskusi pegawai puskesmas yang sedang cuti atau menerima tugas belajar.

Data perubahan kompensasi finansial merupakan data sekunder yang diperoleh dari dokumen laporan keuangan sebelum dan sesudah berlakunya Permenkes 28/2014 dari Dinas Kesehatan dan Puskesmas Kota Cimahi. Data ini berupa nilai rata-rata kompensasi finansial yang diterima pegawai dalam rupiah. Analisis terhadap perbedaan kompensasi finansial sebelum dan sesudah diberlakukannya Permenkes 28/2014 dari satu kelompok sampel dilakukan dengan menggunakan uji komparatif rata-rata dua sampel berkorelasi $t$-test untuk membandingkan kedua data. Adapun hipotesisnya adalah:

Ho : Tidak terdapat perbedaan kompensasi finansial sebelumdan sesudahPermenkes 28/2014.

H1 :Terdapatperbedaan kompensasifinansial sebelum dan sesudah Permenkes 28/2014. Harga $t$ hitung selanjutnya dibandingkan dengan harga $\mathrm{t}$ tabel dengan $\mathrm{dk}=\mathrm{n}-1$, dan taraf kesalahan 5\%. Bila harga t hitung $<\mathrm{t}$ tabel maka Ho diterima dan bila harga $t$ hitung $>t$ tabel Ho ditolak. Pengujian normalitas data digunakan uji Kolmogorov-Smirnov dengan (p) $>0,05$. Sementara itu, bila data tidak berdistribusi normal digunakan uji Wilcoxon. ${ }^{7}$

Penelitian dilaksanakan pada bulan Agustus - November 2016 dan telah mendapatkan kelayakan etik dari Komite Etik Penelitian Kedokteran Kesehatan Fakultas Kedokteran Universitas Padjadjaran Bandung dengan Nomor 915/UN6.C1.3.2/KEPK/PN/2016.

\section{Hasil}

Berdasarkan distribusi statistik dekriptif diketahui bahwa secara keseluruhan, nilai minimal, nilai maksimal dan range kompensasi sesudah Permenkes 28/2014 lebih besar dibandingkan dengan kompensasi sebelum Permenkes 28/2014. Rata-ratakompensasipegawaipuskesmas sebelum Permenkes 28/2014 sebesar Rp.2.319.313,92 lebih kecil bila dibandingkan dengan ratarata kompensasi sesudah Permenkes 28/2014, 
yaitu sebesar Rp.2.449.126,34. Begitu pula dengan nilai median kompensasi sebelum Permenkes 28/201 sebesar Rp.1.843.047,00 lebih kecil bila dibandingkan dengan kompensasi sesudah Permenkes 28/2014, yaitu Rp.2.154.247,00.

Hasil uji normalitas menggunakan Kolmogorov Smirnov diketahui kompensasi sebelum Permenkes 28/2014 maupun kompensasi sesudah Permenkes 28/2014 tidak berdistribusi normal $(\mathrm{p}<0,000)$. Informasi ini dapat dilihat pada Tabel 1. Berdasarkan uji beda diketahui kompensasi sesudah Permenkes 28/2014 lebih besar dari kompensasi sebelum Permenkes 28/2014 sebanyak 112 orang. Sementara kompensasi sesudah Permenkes 28/2014 lebih kecil dari kompensasi sebelum Permenkes 28/2014 sebanyak 38 orang. Hasil uji Wilcoxon menunjukan nilai $Z$ hitung sebesar -4,176 dengan p value sebesar 0.000. Maka Harga Z hitung -4,176 lebih besar dari $\mathrm{Z}$ tabel $=-1,96$, dimana harga (-) tidak diperhitungkan karena harga mutlak.

Dengan demikian uji hipotesisnya adalah H0 ditolak dan H1 diterima. Jadi, dapat disimpulkan terdapat perbedaan rata-rata kompensasi finansial sebelum dan sesudah penerapan Permenkes 28/2014 pada Pegawai Puskesmas di Kota Cimahi.

\section{Pembahasan}

Pada era JKN di Kota Cimahi, kebijakan terkait pengaturan pembagian kompensasi bagi pegawai Puskesmas telah mengalami beberapa kali perubahan. Pertama, dikeluarkan Permenkes 19/2014 tentang Penggunaan Dana Kapitasi Jaminan Kesehatan Nasional untuk Jasa Pelayanan Kesehatan dan Dukungan
Biaya Opersional pada Fasilitas Kesehatan Tingkat Pertama Milik Pemerintah Daerah yang menetapkan pembagian kompensasi berdasarkan variabel jenis ketenagaan/pendidikan dengan kehadiran, dengan sistem perhitungan kumulatif.

Selanjutnya, oleh karena situasi yang tidak kondusif hampir di seluruh daerah, pemerintah kemudian mengeluarkan Permenkes 28/2014 tentang Pedoman Pelaksanaan Program Jaminan Kesehatan Nasional sebagai penyeimbang tingginya kesenjangan nilai variabel dari Permenkes sebelumnya, dengan cara menambahkan variabel daerah yang ditetapkan melalui peraturan daerah.

Dalam rangka menindaklanjuti Permenkes 28/2014, Kepala Dinkes Kota Cimahi telah mengeluarkan peraturan yaitu Berita Acara Rapat Koordinasi Jaminan Kesehatan Nasional (JKN) Puskesmas dan Dinas Kesehatan Nomor 440/3313/Dinkes Tentang Kesepakatan Usulan Variabel Daerah Tahun 2014; dan Keputusan Walikota Cimahi Nomor 440/Kep.13a/ Dinkes/2015 Tentang Penetapan Variabel Daerah dalam Perhitungan Jasa Pelayanan Kesehatan bagi Peserta JKN di Kota Cimahi Tahun 2015.

Pada Berita Acara Rapat Koordinasi, variabel inti yang digunakan dalam pembagian kompensasi adalah pendidikan/ketenagaan dan kehadiran, sedangkan variabel daerahnya meliputi kinerja dinilai dari SKP, status kepegawaian, masa kerja dan golongan. Sistem perhitungan yang digunakan adalah sistem perhitungan proporsi. Kepwal Cimahi 440/2015 ditetapkan dengan tujuan menyederhanakan variabel daerah pada peraturan daerah sebelumnya.

Perubahan variabel daerah meliputi tidak diikutsertakannya status kepegawaian dan golongan, serta diikutsertakannya nilai pemegang

Tabel 1 Distribusi Statistik Deskriptif Kompensasi Finansial Sebelum dan Sesudah Permenkes 28/2014

\begin{tabular}{lcccccc}
\hline \multicolumn{1}{c}{ Variabel } & Min & Maks & Range & Median & Mean & Standar Deviasi \\
\hline $\begin{array}{l}\text { Kompensasi } \\
\text { sebelum }\end{array}$ & 500598 & 8165826 & 7665228 & 1843047.00 & 2319313.92 & 1574468.722 \\
$\begin{array}{l}\text { Kompensasi } \\
\text { sesudah }\end{array}$ & 709095 & 6146749 & 5437654 & 2154247.00 & 2449126.34 & 1163153.745 \\
\hline
\end{tabular}

Tabel 2 Perbedaan Mean Kompensasi Finansial Sebelum dan Sesudah Penerapan Permenkes 28/2014

\begin{tabular}{lcccc}
\hline \multicolumn{1}{c}{ Kompensasi } & N & Mean Rank & Wilxocon $(\boldsymbol{Z})$ & p value \\
\hline Negative Ranks & 38 & 89.05 & & \\
Positive Ranks & 112 & 70.19 & & \\
Ties & 0 & & -4.176 & .000 \\
Total & 150 & & & \\
\hline
\end{tabular}


program, koordinator unit, dan penanggung jawab seluruh program dalam penilaian variabel kinerja. Variabel daerah lain yang diikutsertakan adalah masa kerja.

Adanya perubahan Permenkes tentang pembagian kompensasi bagi pegawai Puskesmas dari Permenkes 19/2014 menjadi Permenkes $28 / 2014$, terbukti ada perbedaan yang signifikan antara rata-rata kompensasi finansial yang diterima pegawai sebelum dan sesudah berlakunya Permenkes 28/2014, yang ditunjukkan dari hasil uji Wilcoxon. Adanya perbedaan yang signifikan ini memperlihatkan bahwa sebenarnya perubahan sistem pembagian kompensasi pada Permenkes 28/2014 sudah baik. Dengan kata lain, peran variabel daerah yaitu masa kerja dan kinerja pada Permenkes 28/2014 dinilai baik karena dapat menyeimbangkan kesenjangan nilai yang tinggi pada variabel inti terutama variabel pendidikan. Adanya perubahan positif sistem pembagian ini juga ditunjukkan dengan adanya kenaikan jumlah kompensasi finansial yang diterima pegawai sesudah diterapkannya Permenkes 28/2014 dibandingkan dengan Permenkes sebelumnya.

Keterbatasan penelitian ini hanya mencangkup pengukuran kepuasan kerja pegawai Puskesmas di Kota Cimahi tehadap kompensasi finansial yang diterimanya berdasarkan Peraturan Menteri Kesehatan Nomor 28 Tahun 2014.

Penelitian menyimpulkan terhadap perbedaan yang signifikan antara kompensasi finansial sebelum dan sesudah penerapan Permenkes 28/2014. Hal ini menunjukan bahwa adanya variabel daerah pada pembagian kompensasi berdasarkan Permenkes 28/2014 dinilai baik.

\section{Daftar Pustaka}

1. Kementerian Kesehatan. 2014. Permenkes No 19 Tahun 2014 tentang Penggunaan Dana Kapitasi Jaminan Kesehatan Nasional untuk Jasa Pelayanan Kesehatan dan Dukungan Biaya Opersional pada Fasilitas Kesehatan Tingkat Pertama Milik Pemerintah.

2. Kementerian Kesehatan. 2014. Peraturan Menteri Kesehatan Republik Indonesia Nomor 28 Tahun 2014 Tentang Pedoman Pelaksanaan Program Jaminan Kesehatan Nasional.

3. Mondy, R. Wayne. Manajemen Sumber Daya Manusia Edisi Ke-10 Jilid 2. Jakarta : Penerbit Erlangga; 2008.

4. Rivai VZ, Mansyur R, Thoby M, Willy A. 2014. Manajemen Sumber Daya Manusia untuk Perusahaan: dari Teori ke Praktik. Edisi ke-3. Jakarta: Raja Grafindo Persada, hlm. 405-437, 541-552, 607-631.

5. Hasibuan, MS. 2014. Manajemen Sumber Daya Manusia. Edisi Revisi. Jakarta: Bumi Aksara; hlm. 117-134, 202-206.

6. Sumintono,B; Wahyu W. 2015. Aplikasi Model Rasch Untuk Penelitian IlmuIlmu Sosial. Edisi Revisi. Cimahi: Trim Komunikata, hlm. 28-29, 89-92, 109-111.

7. Sugiyono. 2014. Statistik Untuk Penelitian. Bandung: Alfabeta, hlm. 260 - 275. 